\title{
ESTUDO COMPARATIVO DO CONHECIMENTO SEXUAL ENTRE ESTUDANTES DE 15 a 17 ANOS, DE NIVEL COLEGIAL, NA GRANDE SÃO PAULO
}

\author{
NOTA PRÉVIA
}

\section{Wanda Escobar da Silva Freddi*}

FREDDI, W. E. da S. Estudo comparativo do conhecimento sexual entre estudantes de 15 a 17 anos, de nível colegial, na Grande São Paulo: nota prévia. Rev. Esc. Enf. USP, São Paulo, 13(3):301, 1979.

O autor propos-se a estudar este assunto por causa do interesse generalizado e recente em educação sexual.

Os objetivos do estudo são:

- verificar o conhecimento real desta área, entre estudantes de 15 a 17 anos, de ambos os sexos, freqüentando o curso colegial e residindo na área da Grande São Paulo;

- verificar em que idade receberam a primeira informação e por quem;

- verificar se moças e rapazes receberam a mesma informação.

$O$ instrumento de coleta de dados é um formulário semi-estruturado, com perguntas sobre a informação recebida, a idade, a fonte da primeira informação concernentes aos seguintes assuntos: órgãos genitais, menstruação, relação sexual (incluindo carícias recíprocas, ereção do penis, ejaculação e polução noturnas), concepção, desenvolvimento do feto no ventre materno, masturbação, homosexualidade, contracepção e doenças venéreas.

O formulário é respondido pelos estudantes na sala de aula, estando presente o pesquisador para esclarecer qualquer dúvida.

A pesquisa encontra-se na fase de coleta de dados.

FREDDI, W. E. da S. A comparative study of the sexual knowledge of 15 to 17 year age high school students of Greater São Paulo: previous note. Rev. Esc. Enf. USP, São Paulo, 13(3):301, 1979.

Considering the recent and generalized interest in sexual education, the author is studying the subject.

The objejctive of the study is to verify:

- the actual knowledge of 15 to 17 year high school students, of both sexes, in the area of Greater São Paulo;

- at what age they received their first information and from whom;

- if boys and girls received the same information.

The instrument for collecting data is a semi-structured questionnaire, with questions on: the information received, age and source of first information on the following matters: sexual organs, menstruation, sexual intercourse (including petting, penis erection, ejaculation and nocturnal emissions), conception, development of the baby in the mother's womb, masturbation, homosexuality, contraception and venereal diseases.

The questionnaire is answered by the students in the classroom, being the researcher present to clarify any possible doubts.

The study is at the data collecting phase.

\footnotetext{
* Professor Assistente Doutor das disciplinas Enfermagem Obstétrica e Neonatal e Enfermagem Ginecológica da EEUSP.
} 